\title{
Evaluation of human dental stem cell growth characteristics and cellular morphological changes in response to extracellular matrix nanotopography
}

\author{
- Vaishnavi Dhanvantri N Department of Oral Pathology, SRM Dental College and Hospital, Chennai, TN, India • Ramya R \\ Department of Oral Pathology, SRM Dental College and Hospital, Chennai, TN, India • Kotturathu Mammen Cherian Department \\ of Regenerative Medicine, Frontier Lifeline Pvt, Chennai, TN, India • Balasundari Ramesh Department of Regenerative \\ Medicine, Frontier Lifeline Pvt, Chennai, TN, India
}

ABSTRACT | Objective: Nanotopography and soluble extracellular factors are present in the dental stem cell niche in the pulp. Their effect on dental stem cell survival and differentiation is yet to be established. We aimed to analyze the individual and combined roles of extracellular matrix (ECM) nanotopography and serum (soluble factors) on the growth, differentiation potential, and morphological characteristics of the human dental pulp stem cells (hDPSC). This study aimed to evaluate and compare the hDPSC response to different environmental cues - nanofibers, serum, and conditioned media. Materials and methods: In this study, fabricated PLLA nanofibers were used as the in vitro structural biomimetic of the native nanotopography found in the in vivo ECM/stem cell niche. Serum and conditioned media were used as the in vitro mimic of the soluble factors to which stem cells get exposed in vivo. hDPSC were grown in the presence and absence of biodegradable poly-L-lactic-acid nanofibers and serum. The growth characteristics of hDPSC were assessed in terms of cell viability and doubling time at the interval of every passage. Cellular morphological changes were studied using inverted microscopy and H\&E. As the second part of the study, hDPSC in all culture conditions were exposed to Dental Pulp Conditioned Media (DPCM) for a short duration of 3 days. After transient exposure to DPCM, the growth characteristics and the morphological changes of hDPSC were assessed. In addition, scanning electron microscopy was used for the morphological study of hDPSC on nanofibers, exposed to conditioned media. The differentiated cells were analyzed by qRT-PCR for neurogenic and odontogenic expression of RUNX2, osteopontin, and $\beta$-tubulin III genes. Results: hDPSC showed better survival and proliferation in the presence of nanofibers and serum. Absence of nanofibers or serum greatly altered stem cell survival and proliferation and also indicated differentiation. In addition, it was observed that after transient exposure to DPCM, the presence of both PLLA nanofiber and serum favoured higher odontogenic and neurogenic differentiation potential, without characteristic morphological changes of terminal differentiation. Conclusion: hDPSC has the ability to sense nanoscale geometric cues from their microenvironment. Nanotopography and soluble factors of the extracellular matrix both affect hDPSC. Further studies are essential to identify the key pathways that play a vital role in such interactions.

DESCRIPTORS | Dental Pulp Stem Cells; Nanofibers; Conditioned Media; Nanotopography; Poly Lactic Acid.

RESUMO | Avaliação das características de crescimento de células-tronco dentárias humanas e alterações morfológicas celulares em resposta à nanotopografia por matriz extracelular - Objetivo: Nanotopografia e fatores extracelulares solúveis estão presentes nas célulastronco da polpa dentária Seu efeito na sobrevivência e diferenciação de células-tronco dentárias ainda não foi estabelecido. Nosso objetivo foi analisar os papéis individuais e combinados da nanotopografia e do soro (fatores solúveis) da matriz extracelular (MEC) no crescimento, potencial de diferenciação e características morfológicas das células-tronco da polpa dentária humana. Este estudo avaliou e comparou a resposta de tais células-tronco a diferentes estímulos ambientais - nanofibras, soro e meios condicionados. Materiais e métodos: Neste estudo, nanofibras de PLLA fabricadas foram usadas como meio biomimético estrutural in vitro da nanotopografia nativa encontrada na polpa de células-tronco/MEC in vivo. O soro e o meio condicionado foram utilizados como o imitador in vitro dos fatores solúveis aos quais as células-tronco são expostas in vivo. As células-tronco foram cultivadas na presença e ausência de nanofibras de ácido poli-L-lático biodegradáveis e soro. As características de crescimento das células-tronco da polpa dentária humana foram avaliadas em termos de viabilidade celular e tempo de duplicação no intervalo de cada passagem. As alterações morfológicas celulares foram estudadas usando microscopia invertida e coloração H\&E. Como segunda parte do estudo, as células em todas as condições de cultura foram expostas ao Meio Condicionado para Polpa Dentária (MCPD) por um curto período de 3 dias. As características de crescimento e as alterações morfológicas das células foram avaliadas após a exposição curta ao MCPD. Além disso, a microscopia eletrônica de varredura foi utilizada para o estudo morfológico das células-tronco em nanofibras, expostas aos meios condicionados. As células diferenciadas foram analisadas por TR-PCR quantitativa quanto à expressão neurogênica e odontogênica dos genes RUNX2, osteopontina e $\beta$-tubulina III. Resultados: As células-tronco dentárias apresentaram melhor sobrevida e proliferação na presença de nanofibras e soro. A ausência de nanofibras ou soro alterou a sobrevivência e proliferação de células-tronco de forma significativa e indicou diferenciação. Além disso, observou-se que, após a exposição curta ao MCPD, a presença de nanofibras e soro de PLLA favoreceu maior potencial de diferenciação odontogênica e neurogênica, sem alterações morfológicas características da diferenciação terminal. Conclusão: Células-tronco da polpa dentária humana são capazes de detectar sinais geométricos em nanoescala de seu microambiente. Nanotopografia e fatores solúveis da matriz extracelular afetam as células-tronco. Estudos adicionais são essenciais para identificar os principais caminhos que desempenham um papel vital nessas interações.

DESCRITORES | Células-tronco da Polpa Dentária; Nanofibras; Meio Condicionada; Nanotopografia; Ácido Polilático.

CORRESPONDING AUTHOR | Balasundari Ramesh Department of Regenerative Medicine • Frontier Lifeline Pvt. Ltd, Ambattur Industrial estate Road, R30C

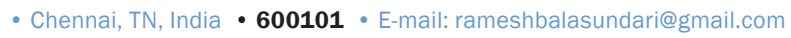

- Received July 26, 2019 • Accepted Oct. 21, 2019

- Dol http://dx.doi.org/10.11606/issn.2357-8041.clrd.2019.160296 


\section{INTRODUCTION}

Stem cells are defined functionally as cells that have the capacity to self-renew as well as the ability to generate differentiated cells., ${ }^{1,2}$ The dental stem cells are considered to be multipotent adult stem cells that can be isolated from adult dental pulp, deciduous teeth, natal dental pulp, periodontal ligament, dental follicle, and apical papilla. ${ }^{3-7}$ Human Dental Pulp Stem Cells (hDPSC) were the first type of dental stem cells to be isolated. ${ }^{8}$ Understanding the nature of the dental stem cell populations in the pulp is important for determining their potentialities in the development of isolation or recruitment strategies and tissue engineering, as well as to understand stem cell response in different pulpal pathologies.9,10

Various studies have been carried out to detect the influences of extracellular matrix (ECM) nanotopography on dental stem cells that affect cell survival and differentiation. ${ }^{11,12}$ Electrospun nanofiber polymer scaffolds had also supported adhesion of hDPSC and improved their differentiation in a few studies. ${ }^{13}$ It is also well established that soluble factors, including growth factors, proteins, hormones, cytokines, and other small molecules, can exert potent and specific effects in the stem cell microenvironment. ${ }^{14,15}$ However, the combined effect of ECM nanotopography and serum on human dental pulp stem cells has not been studied so far.

Analyzing the individual and combined roles of ECM nanotopography and serum on the growth, differentiation potential, and morphological characteristics of hDPSC helps understanding the environment to which dental pulp stem cells are exposed, in the dental pulp stem cell niche in vivo. ${ }^{16,17}$ It also provides an insight about the way human dental pulp stem cells survive and about the regenerative and repairing process in which they participate during physiological and pathological conditions in the dental pulp. ${ }^{18-20}$ In this study, we aimed to analyze the individual and combined roles of ECM nanotopography and soluble factors (serum and DPCM) on the growth, differentiation potential, and morphological characteristics of hDPSC.

\section{MATERIALS AND METHODS}

This study was conducted after due approval by the institutional research and ethical committees of the Frontier Lifeline Hospital. Nanofibers were used as the in vitro biomimetic of the nanotopography found in the $\mathrm{ECM} /$ stem cell niche in vivo. Serum and conditioned media were used as the in vitro mimic of the soluble factors to which stem cells get exposed in vivo.

\section{Isolation and expansion of hDPSC}

Dental pulp stem cells were isolated from wisdom teeth donated by ten healthy volunteers aged 15-34 years. The outer surface of the teeth were sterilized using ethanol $70 \%$ and transported at $4{ }^{\circ} \mathrm{C}$ in Dulbecco's Modified Eagle Medium (DMEM - Gibco 119950) and antibiotic cocktail containing $50 \mathrm{U} / \mathrm{ml}$ penicillin, $50 \mu \mathrm{g} / \mathrm{ml}$ streptomycin, and $0.25 \mathrm{mg} / \mathrm{ml}$ amphotericin B (HiMedia Aoo2A). The dental pulp tissue extracted from the teeth was minced and digested using Dulbecco's phosphate buffered solution (DPBS - HiMedia TS1006) containing $3 \mathrm{mg} / \mathrm{ml}$ collagenase (Sigma C9722) and $4 \mathrm{mg} / \mathrm{ml}$ dispase protease (Sigma D4693) for 1 hour at $37{ }^{\circ} \mathrm{C}$. The digested suspension was filtered using $70-\mu \mathrm{m}$ cell filter. Finally, the single-cell suspensions were divided equally for cultivation in two types of primary culture media (serum-free DMEM and 10\% fetal bovine serum (FBS - Gibco 26140079) supplemented with DMEM media). The culture dishes/plates were incubated at $37^{\circ} \mathrm{C}$ in a humidified atmosphere containing $5 \%$ $\mathrm{CO}_{2}$, and both culture media were changed every 3 or 4 days. At $80 \%$ confluence, the cultured cells were detached using TrypLE Select (Thermo Fisher Scientific) and were subcultured at $5 \times 10^{3}$ cells $/ \mathrm{cm}^{2}$ in 6 well culture dishes (Falcon). Cells at passage 4 were used for nanotopographic experiments and some confluent plates were passaged and cryopreserved using CryoStor (CS1O, Sigma Aldrich). All experiments 
were repeated independently in triplicates. Population Doubling Time (PDT) and viability analysis of the isolated hDPSC were also performed.

Cell-surface-marker expression analysis for hDPSC was performed by flow cytometry. Sub-confluent cells were trypsinized and fixed with $4 \%$ paraformaldehyde (PFA) for 20 minutes at room temperature. After washing with DPBS by centrifuging at $1500 \mathrm{rpm}$ for 10 minutes, the fixed cells were incubated with monoclonal antibodies (Abcam) against human CD9o/ Thy1 (ab23894), CD146 (ab78451), CD105 (ab109215), CD166 (ab11414), CD13 (ab7417) and negative markers CD34 (ab81289) and CD 45 (ab40763) and conjugated secondary antibodies fluorescein isothiocyanate (FITC, ab6730) and phycoerythrin-conjugated (PE, ab 72465). Flow-cytometric analysis was performed using a Guava $^{\mathrm{TM}}$ easyCyte HT system and Guava ${ }^{\mathrm{TM}}$ Express Plus software (version 2.7; Merck KGaA).

\section{Preparation of Dental Pulp Conditioned Media (DPCM)}

The extracted dental pulp was minced using sterile protocol. Serum-free medium (SFM) StemPro
(Thermo Fisher Scientific) was added and incubated under $5 \% \mathrm{CO}_{2}$ and $37^{\circ} \mathrm{C}$ for 2 days. The media was then centrifuged at $1500 \mathrm{rpm}$ for 10 minutes and filtered with $0.2 \mu \mathrm{m}$ cellulose acetate filters to remove the cell debris. The filtered sterile conditioned media from pulp tissue was stored at a $-80{ }^{\circ} \mathrm{C}$ freezer. This conditioned media was thawed and used for the hDPSC differentiation experiment.

\section{Preparation of Electrospun Nanofiber Scaffolds}

The electrospun nanofibers were obtained from 15\% w/v poly-L-lactic-acid (PLLA, \#93578, Sigma Aldrich) dissolved in 1,1,1,3,3,3-Hexafluoro-2propanol (HFIP, T63002, Sigma Aldrich). Electrospinning experiments were performed with a customized device (E-spin Nanotech) using $17 \mathrm{kV}$, a flow rate of $4 \mathrm{~mL} / \mathrm{h}$, and an $18 \mathrm{G}$ needle at an electrode distance of $18 \mathrm{~cm}$. The random fibers were collected using glass coverslips. Finally, the coverslips of electrospun nanofibers were sterilized using 70\% ethanol and UV irradiation at $254 \mathrm{~nm}$ for 2 hours prior to all cell culture experiments (Figure 1).

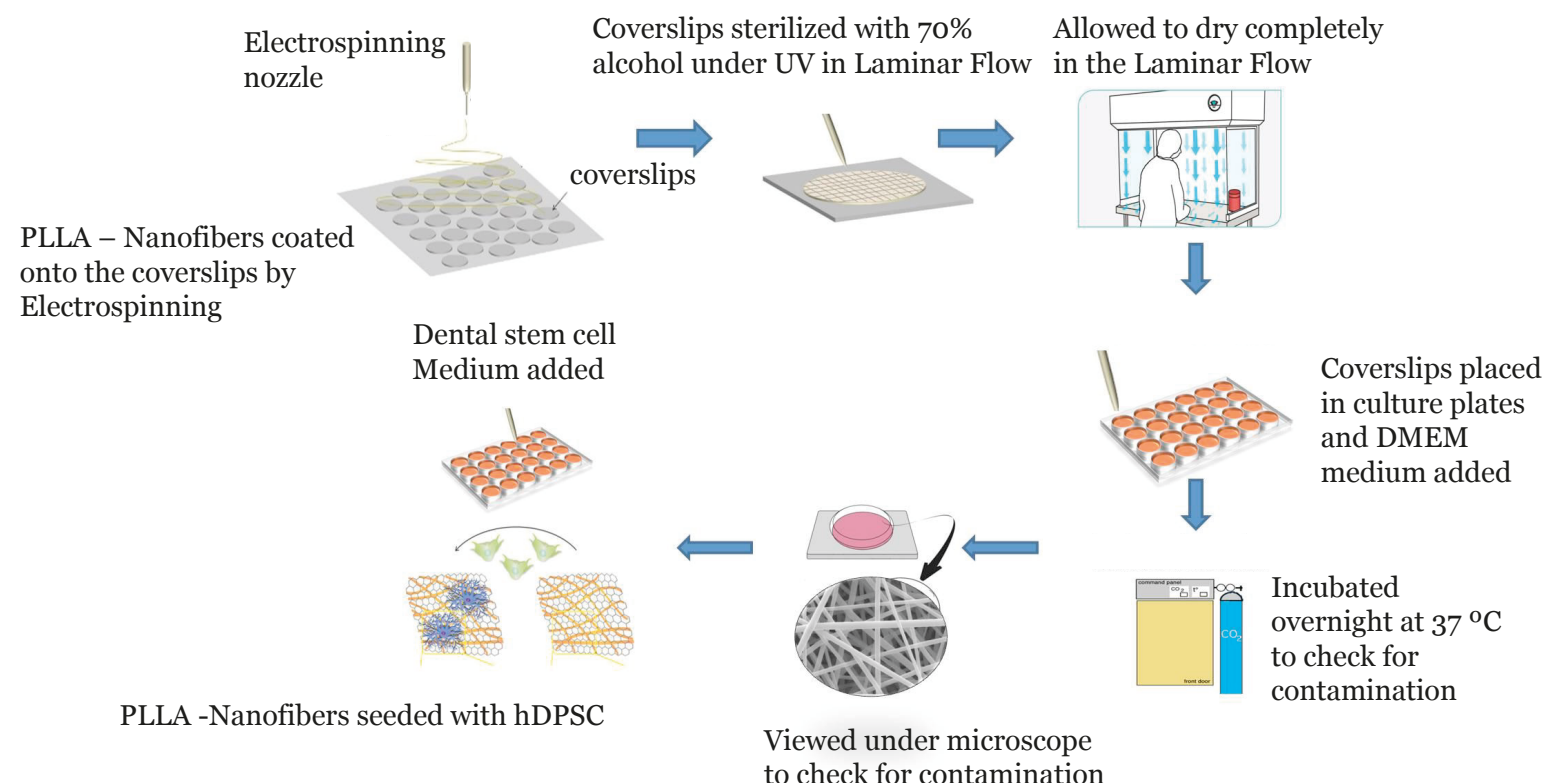

Figure 1 | Schematic diagram representing the electrospinning and cell seeding techniques to prepare nanofiber coated coverslips for hDPSC culture. 
The morphology of the electrospun scaffolds was determined using a scanning electron microscope (SEM, Zeiss, 1530 VP). After platinum sputter coating, images were acquired at a distance of $8 \mathrm{~mm}$ from the detector, with a voltage of $15 \mathrm{kV}$ and different magnifications. Image ${ }^{\circledR}$, supplied with the DiameterJ plug-in, was used for fiber diameter analysis.

Uniaxial tensile testing of the nano-scaffolds was performed. The sheets of electrospun nanoscaffolds were cut into $10 \mathrm{~mm} \times 20 \mathrm{~mm}$ rectangular pieces and clamped into the uniaxial tensile testing device (Instron). The exact sample dimensions were determined before each measurement and recorded with the software for further calculations of Young's modulus (E) and tensile strength. The scaffolds were pulled to failure by applying a stretch of $0.025 \mathrm{~mm} / \mathrm{s}$ at a temperature of $23{ }^{\circ} \mathrm{C}$ and humidity of $50 \%$. The Young's modulus was calculated from the initial linear slope of the stress versus strain curve for each measurement. The measured values are presented as mean \pm standard deviation (each group $\mathrm{n}=3$ ).

The PLLA nanofibers were subjected to Attenuated Total Reflection Fourier-Transform Infrared Spectroscopy (ATR-FTIR) analysis to detect the presence of $\beta$-sheet secondary structures and to identify functional groups and characterize covalent bonding information. The samples were clamped to the ATR crystal. Then, the infrared spectra were recorded at (4000-650) $\mathrm{cm}^{-1}$ region with a resolution of $4.0 \mathrm{~cm}^{-1}$ and 16 scan using universal ATR sampling accessory.

In vitro cytotoxicity of the nanofibers was determined prior to cell culture experiments, as per ISO 10993 accredited protocol. The sterilized coverslips with nanofibers were washed gently with Dulbecco's Modified Eagle Medium (DMEM, HyClone) and placed in 6 well plates (Falcon). The coverslips were seeded with $1 \times 10^{6}$ Balb c/3T3 fibroblasts and incubated with complete media that consist of $10 \%$ fetal bovine serum (FBS, Gibco) and
DMEM. After 24 hours of incubation, the medium was removed and CellTiter 96 Aqueous One Solution Cell Proliferation Assay (Promega) was performed according to the manufacturer's protocol. Briefly, $20 \mu \mathrm{L}$ of MTS solution was added to $100 \mu \mathrm{L}$ of culture media. After incubation for 35 minutes at $37^{\circ} \mathrm{C}$, the absorbance of each well was measured at $492 \mathrm{~nm}$ using spectrophotometer. The test was performed for a blind, a negative control (NC; DMEM + 10\% FBS) and a sodium dodecyl sulfate (SDS, Life Technologies GmbH, 1\% in DMEM) treated positive control (PC). For analysis, the NC was set to $100 \%$. The non-cytotoxic nanofibers were subjected to cell culture experiments using hDPSC.

\section{hDPSC culture in vitro experiment}

To analyze the individual and combined roles of ECM nanotopography and soluble factors of serum, hDPSC were subjected to four different culture conditions.

1. Control hDPSC in cell culture plates with DMEM supplemented with 10\% FBS

2. Control hDPSC in cell culture plates with serum-free media (SFM, StemPro)

3. Test cultures hDPSC seeded on nanofibers and cultured with DMEM supplemented with 10\% FBS

4. Test cultures hDPSC seeded on nanofibers and cultured with SFM (StemPro)

hDPSC were grown in the presence and absence of biodegradable poly-L-lactic-acid nanofibers and serum (FBS). For the test cultures on nanofibers, the coverslips with nanofibers were placed on polyethylene terephthalate hanging cell culture insert with pore size of $0.4 \mu \mathrm{m}$ (Millicell) in 6 well culture plates (Falcon). Every experiment was done in triplicates, with seeding density of 10000 cells $/ \mathrm{cm}^{2}$ under the growth conditions of $37^{\circ} \mathrm{C}$ and $5 \% \mathrm{CO}_{2}$.

At the interval of every passage, the growth characteristics of hDPSC were assessed in terms of 
cell viability and population doubling time (PDT) in the different culture conditions. To calculate PDT, the cultured cells were detached using trypsin-EDTA and routinely counted and checked for viability in triplicates using Neubauer chamber and Trypan blue stain (0.4\%, TC193, HiMedia) at every passage. PDT was calculated using the following formula:

$$
\mathrm{PDT}=\left(t-t_{0}\right) \log 2 / \log \left(N-N_{\mathrm{o}}\right)
$$

where $t$ is time (hours), $N$ is the number of cells, and $N_{\text {o }}$ and $N$ represent the number of cells at $t_{0}$ and $t$, respectively.
The results were analysed using GraphPad Prism 5. Two-way ANOVA was performed to compare the stem cell viability percentages of passages, the cell count, and proliferation of cultures, in the presence and absence of nanofibers and serum. The stem cell doubling time in the presence and absence of nanofibers was compared by using paired t-test.

The cellular morphological changes were studied by inverted microscopy and $\mathrm{H} \& \mathrm{E}$. The observations were taken every week and the changes were photographed. The protocol used for the study is summarized in Figure 2.

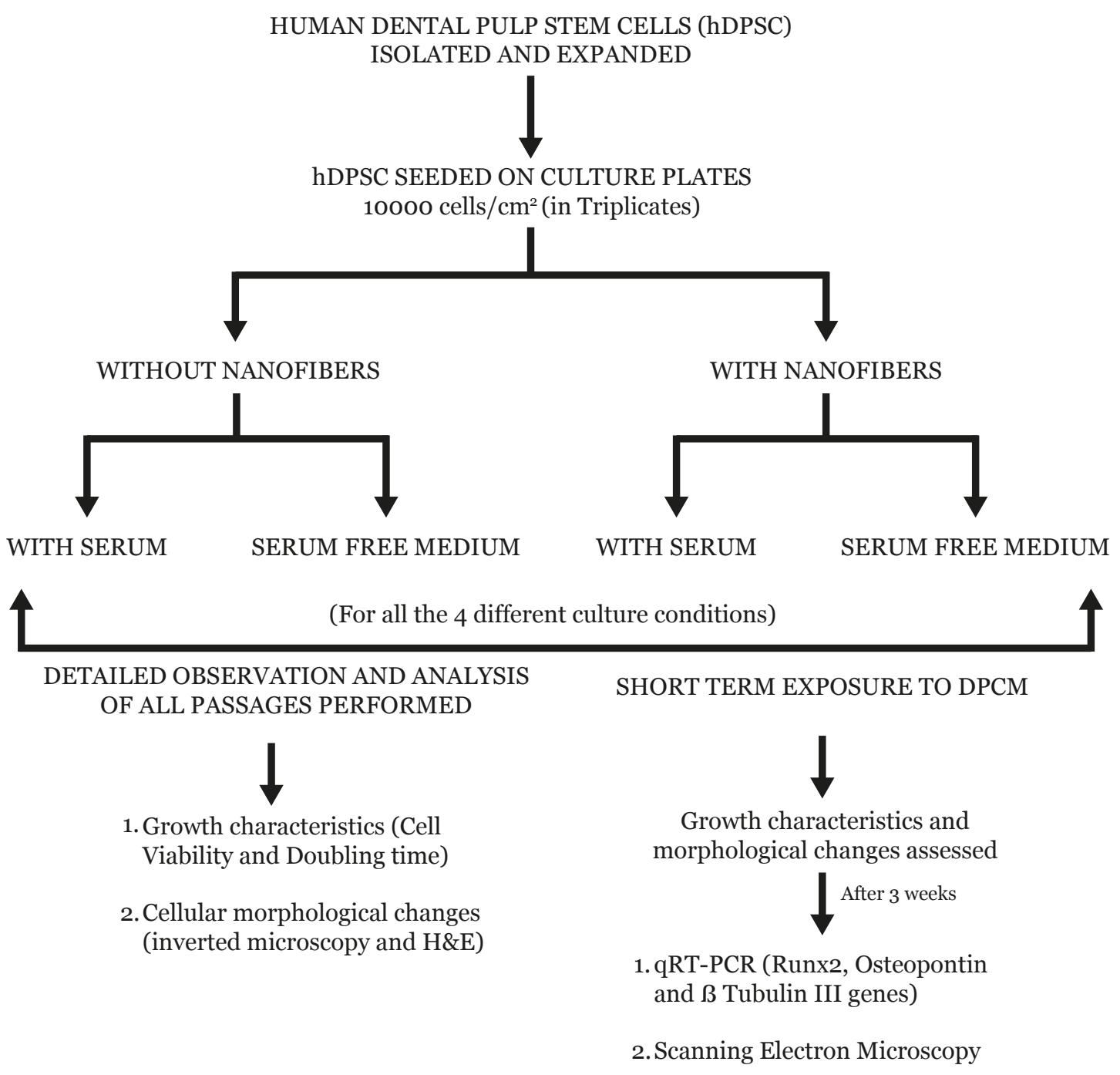

Figure 2 | Flowchart summarizing the protocol used for the study. 
As the second part of the study, hDPSC in the four different culture conditions were exposed to DPCM in the ratio of 1:3 mixed with complete media, for a short duration of 3 days. After the short-term exposure to conditioned media, comparison of the growth characteristics and the morphological changes in the presence and absence of nanofibers and serum was done for a period of 3 weeks. Inverted microscopy was used to assess the stem cell morphology under all culture conditions. In addition, scanning electron microscopy (SEM) was used for the morphological study of hDPSC on nanofibers exposed to conditioned media. The differentiated cells were analyzed by Quantitative Real-Time Polymerase Chain Reaction Analysis (qRT-PCR) for the differential expressions of two odontoblast genes - osteopontin (OPN) and runt-related transcription factor 2 (RUNX2), and also beta tubulin III ( $\beta$-tubulin III), a microtubule element expressed exclusively in neurons.

\section{Real-time PCR}

The four groups of cells exposed to DPCM (PLLA nanofibers with serum, PLLA nanofibers with SFM, control hDPSC with serum, and control hDPSC with SFM) were subjected to real-time PCR analysis for the differential expressions of OPN, RUNX2, and $\beta$-tubulin III genes after 3 weeks. Total RNA was subsequently isolated using TRIzol ${ }^{\circledR}$ reagent (Sigma). All RNA samples were checked for purity using a ND1000 spectrophotometer (Nano Drop Technologies). Total RNA samples were reverse transcribed into
cDNA using the ThermoScript ${ }^{\mathrm{TM}}$ RT-PCR system (Invitrogen). The addition of equal amounts of RNA $(1 \mu \mathrm{g})$ to each RT reaction was necessary to yield highly consistent results. Quantitative real-time PCR was performed using $1 \mu \mathrm{g}$ of cDNA and Maxima SYBR Green/ROX qPCR Master Mix (Thermo Fisher) in a LightCycler ${ }^{\circledR} 480$ Instrument (Roche Life Science). The primer sequences are shown in Table 1 . The PCR reactions were carried out in a $20 \mu \mathrm{l}$ reaction volume, containing $20 \mathrm{mM}$ Tris/ $\mathrm{HCl}(\mathrm{pH} \mathrm{8.4),50} \mathrm{mM} \mathrm{KCl,}$ $1.5 \mathrm{mM} \mathrm{MgCl} 2,0.2 \mathrm{mM}$ of each dNTP, $1 \mu \mathrm{M}$ of each primer, $1 \mu \mathrm{M}$ fluorescein, SYBR ${ }^{\circledR}$ Green dye stock diluted down to 200 times, 0.5 unit/ $\mu$ l Platinum Taq Polymerase (Invitrogen), and $1 \mu \mathrm{l}$ of template resulting from the reverse transcription reaction. About 4050 cycles were performed in BioRad iCycler, each consisting of a 30 -second denaturation at $94^{\circ} \mathrm{C}$, a 30 -second primer annealing at $60^{\circ} \mathrm{C}$ (for $\beta$-tubulin III) and $65^{\circ} \mathrm{C}$ (for GAPDH, osteopontin, and RUNX2), and a 15 -second elongation at $72{ }^{\circ} \mathrm{C}$. The raw data was then analyzed with the Relative Expression Software Tool (REST) using the automatic cycle threshold (Ct) setting to assign baselines and thresholds for the $\mathrm{Ct}$ determination. Delta $\mathrm{Ct}(\Delta \Delta \mathrm{CT})$ values were used for this analysis. The Relative Expressions (REs) of the sample genes were calculated using the $\Delta \Delta \mathrm{CT}$ method, and GAPDH was used as the internal control or housekeeping gene. The qRT-PCR experiments were carried out at least three times. Data were presented as mean \pm SEM (standard error of the mean). Statistical significance was analyzed with paired Student t-test.

TABLE 1 || Primers for qRT-PCR

\begin{tabular}{|c|c|c|}
\hline Gene & Primers & Gene bank \\
\hline RUNX2 & $\begin{array}{l}\text { 5'-AAGTGCGGTGCAAACTTTCT-3' } \\
\text { 5'-TCTCGGTGGCTGCTAGTGA-3' }\end{array}$ & NM_001015051.3 \\
\hline Osteopontin & $\begin{array}{l}\text { 5'-AAGGCGCATTACAGCAAACACTCA } \\
\text { 3'- CTCATCGGACTCCTGGCTCTTCAT }\end{array}$ & NM_001040058.1 \\
\hline GAPDH & $\begin{array}{l}\text { 5'- ACCACAGTCCATGCCATCAC } \\
\text { 3'- TCCACCACCCTGTTGCTGTA }\end{array}$ & NM_002046.6 \\
\hline
\end{tabular}




\section{RESULTS}

The isolated and expanded hDPSC (passage 2 cells) were positive for CD9o, CD146, CD166, CD105, CD13 and negative for markers CD45 and CD34 (Figure 3). The primary cultures of hDPSC showed colony forming unit (CFU, Figure 4A). hDPSC presented fibroblast-like morphology with prominent nucleus and granular cytoplasm (Figure 4). The PLLA nanofibers used for the hDPSC cultures had smooth scaffold with thickness at an average of
$0.040 \mathrm{~mm}$. The nanofibers had a density of 0.202 , a diameter from 0.730 to $0.754 \mu \mathrm{m}$, and a contact angle of 118.2 degrees. The mean weight of each scaffold was $1.87 \mathrm{mg}$. They had a tensile modulus of $3.2 \pm 0.4$ $\mathrm{GPa}$, tensile strength of $178 \pm 25 \mathrm{MPa}$, and strain at break of $0.42 \pm 0.11 \%$. The FTIR analysis showed sharp curves from 2000 to 1000 wavenumbers $\mathrm{cm}^{-1}$ (Figure 6 lower pane). The cytotoxicity experiments with $3 \mathrm{~T}_{3}$ cells showed that the PLLA nanofibers are non-cytotoxic.
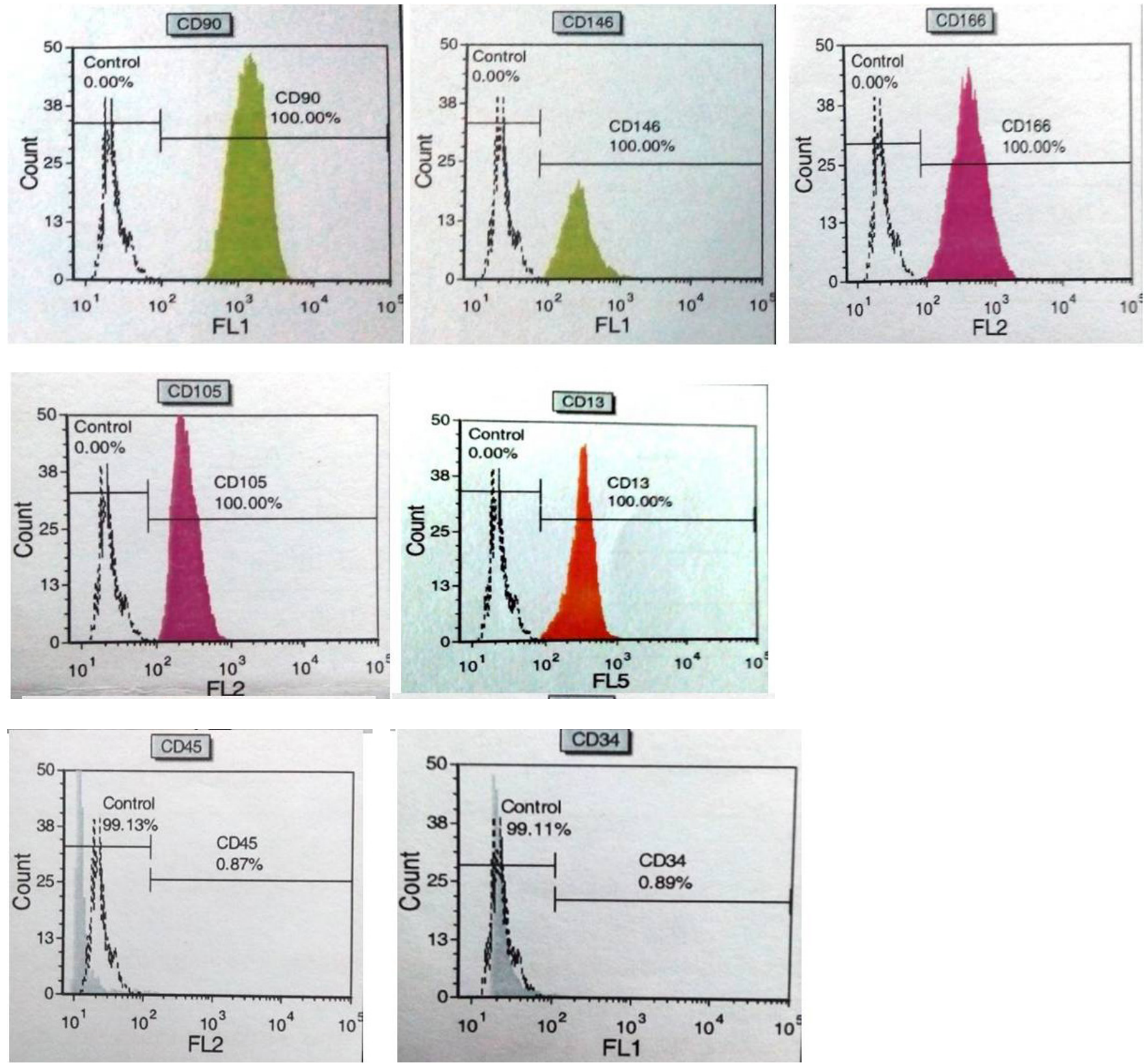

Figure 3 | Flow cytometry analysis: Positive Markers: CD90, CD146, CD166, CD105, and CD13 Negative Markers: CD45 and CD34. 

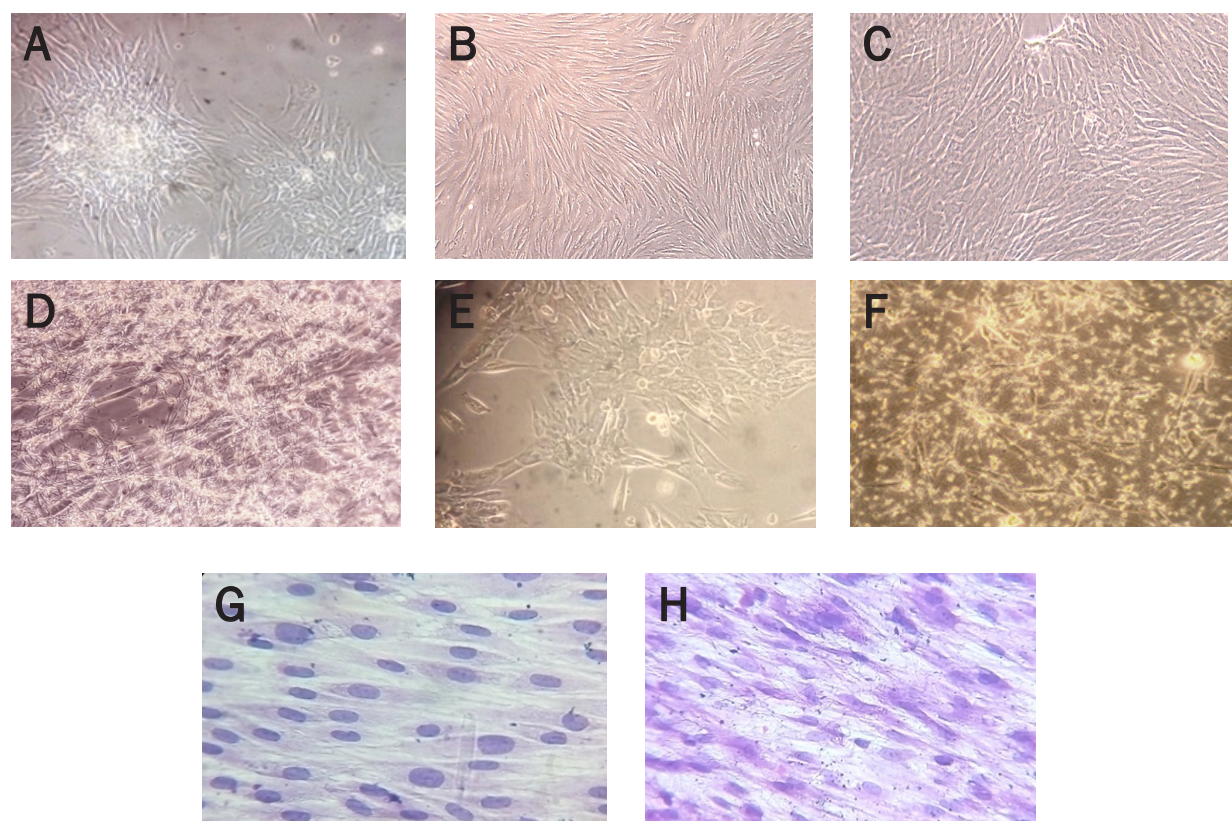

Figure 4 | Cell culture morphology analysis. A: Colony forming units of primary culture of hDPSC $\times 100$; B: Passage two confluent cells $\times 100$; C: Control hDPSC in cell culture plates with serum $\times 100$; D: Test culture hDPSC seeded on nanofibers and cultured with serum showing spindle shaped cells in close interaction with nanofibers $\times 100$; E: Control hDPSC in cell culture plates with serum-free media showing cells with shorter cytoplasmic extensions $\times 100$; F: Test cultures hDPSC seeded on nanofibers and cultured with serum-free media with long cytoplasmic extensions and spindle shape $\times 100$; G: H\&E stained hDPSC grown on cell culture 2D plates $\times 400 ; \mathrm{H}-\mathrm{H} \& \mathrm{E}$ stained stem cells on PLLA nanofibers $\times 400$.
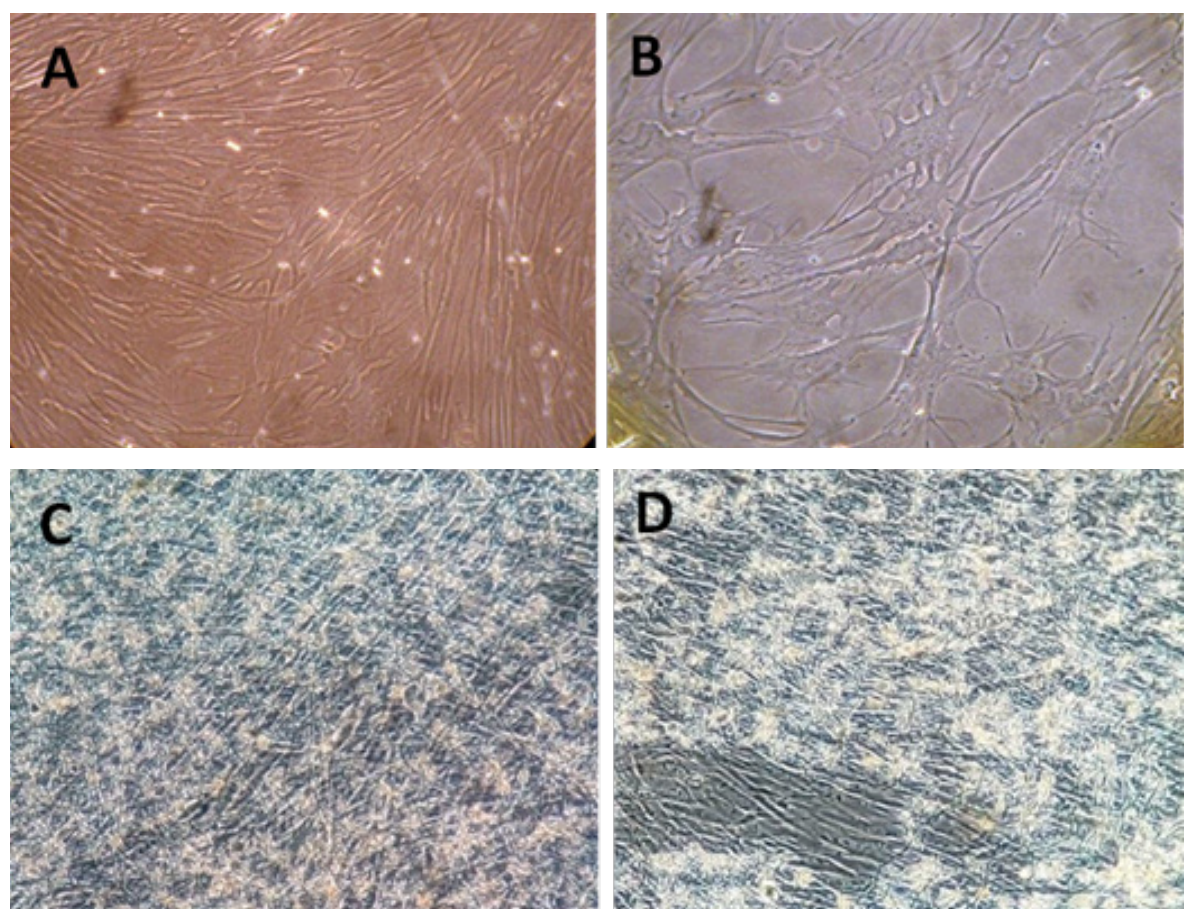

Figure 5 | 3 weeks post differentiation: A: hDPSC grown under the influence of serum (FBS) $\times 200$ magnification showing typical neuron-like morphology - cell bodies with extended cytoplasmic processes in contact with the nanofibers and the adjacent cells forming a network-like appearance; B: hDPSC grown under the influence of serum-free media (SFM) $\times 200$ magnification with typical neuron-like morphology indicating differentiation; C: hDPSC grown under the influence of PLLA nanofiber and FBS, retaining the spindle shaped fibroblast-like morphology, in close interaction with the nanofibers $\times 200$; D: hDPSC grown under the influence of PLLA nanofiber and SFM, retaining the spindle shaped fibroblast-like morphology $\times 200$. 

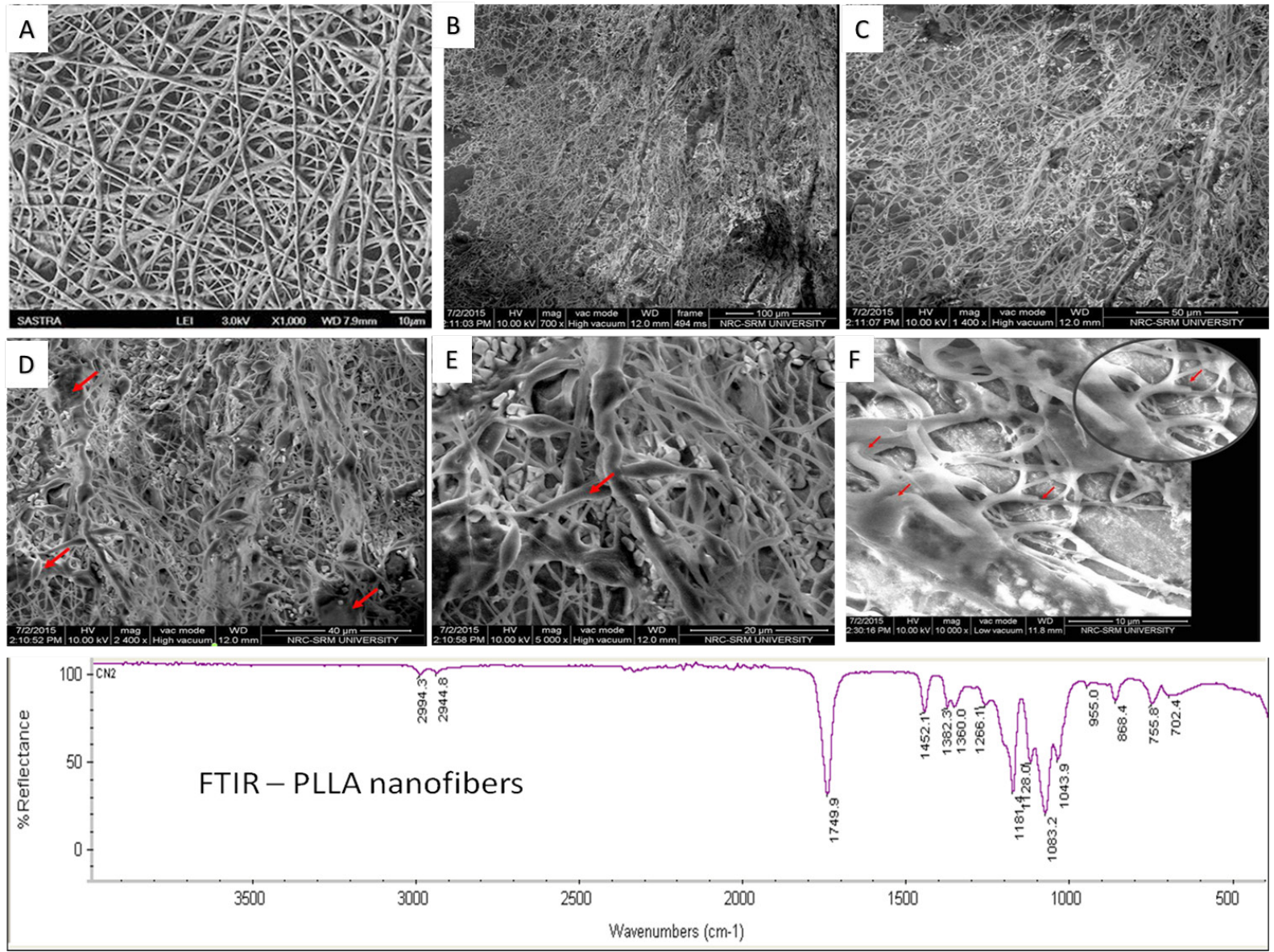

Figure 6 | Scanning Electron Microscopic images. A: PLLA nanofibers; B \& C: PLLA nanofibers seeded with hDPSC and 3 weeks post differentiation; D \& E: SEM images show close contact and interaction of the hDPSC cytoplasmic processes with the nanofibers, indicating nanotopographic contact guidance of the cellular morphology; F: SEM image shows a small short cell with multiple elongated cytoplasmic processes in contact with the nanofibers and the adjacent cell. Lower pane: FTIR graph of PLLA nanofibers.

\section{Growth characteristics of hDPSC}

The mean percentage viability of hDPSC at passages 2, 4, and 6 are represented in graph (Figure 7). The growth characteristics were similar in all passages. The cells that were cultured in the absence of nanofibers and serum had the least viability percentage (69.12\%). The cells that were cultured in the presence of both nanofibers and serum had the highest viability percentage (97.01\%). When serum was added to the cultures, no statistically significant difference was found in the cell viability in the presence and absence of nanofibers $(\mathrm{P}>0.05)$. However, under serumfree culture conditions, a statistically significant increase in cell viability was observed on nanofibers, higher than on culture plates. The difference in the viability was as high as $13.35 \%$ on nanofibers, indicating greater survival and proliferation on nanofibers $(\mathrm{P}<0.0001)$. When cultured without nanofibers, hDPSC had a doubling time of 28 hours with serum and 68 hours without serum. hDPSC cultured on PLLA nanofibers had a doubling time of 26 hours with serum and 42 hours without serum. Statistically significant difference was found between the doubling time of cultures, in the presence and absence of nanofibers. The stem cells without nanofibers had higher doubling time, indicating slower proliferation in the absence of nanofibers. 


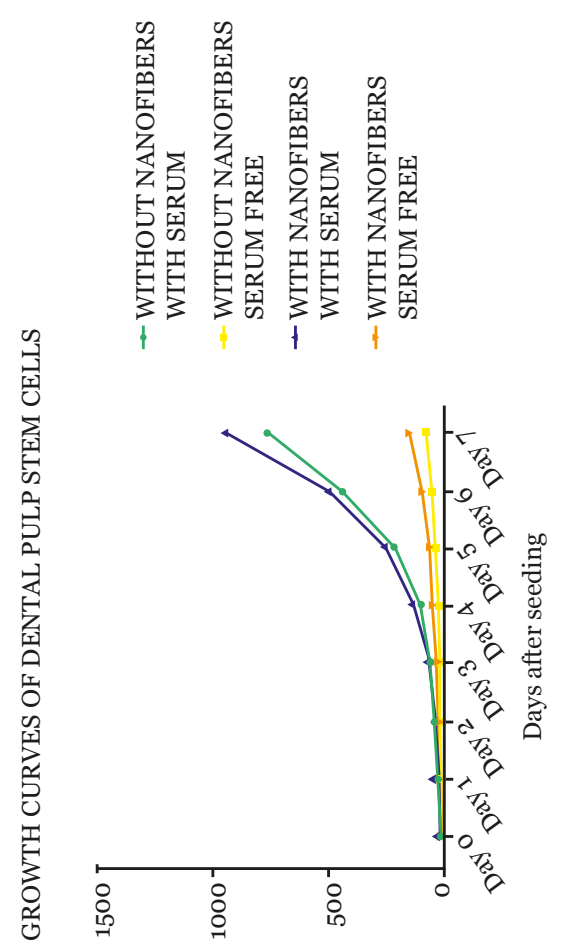

${ }_{\varepsilon} \mathrm{OL} \times[\mathrm{W} / \mathrm{s}[\mathrm{I}$ ว

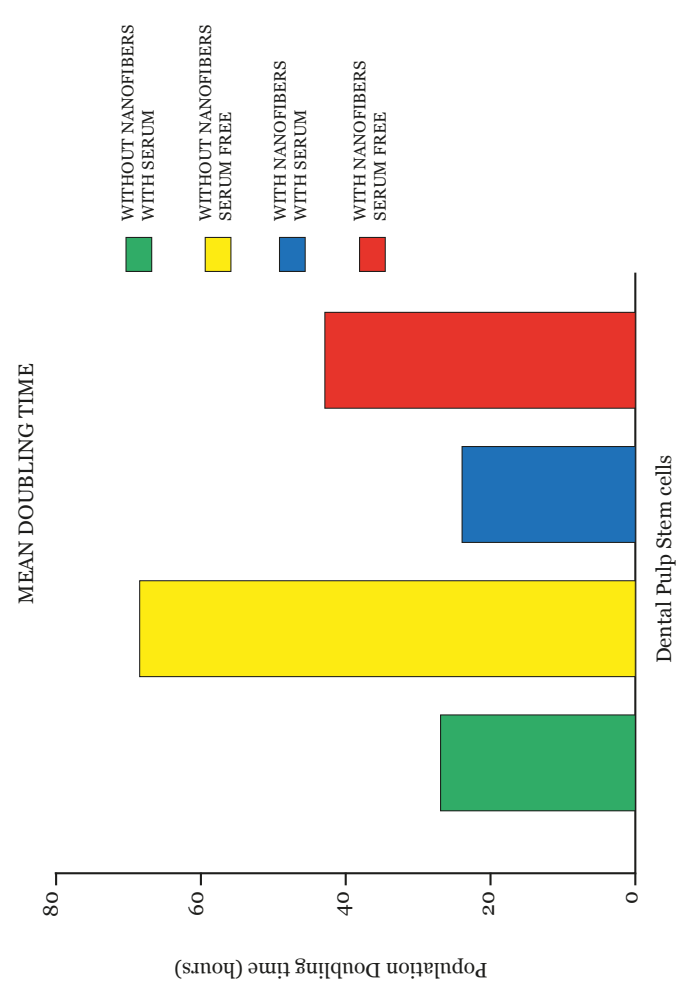

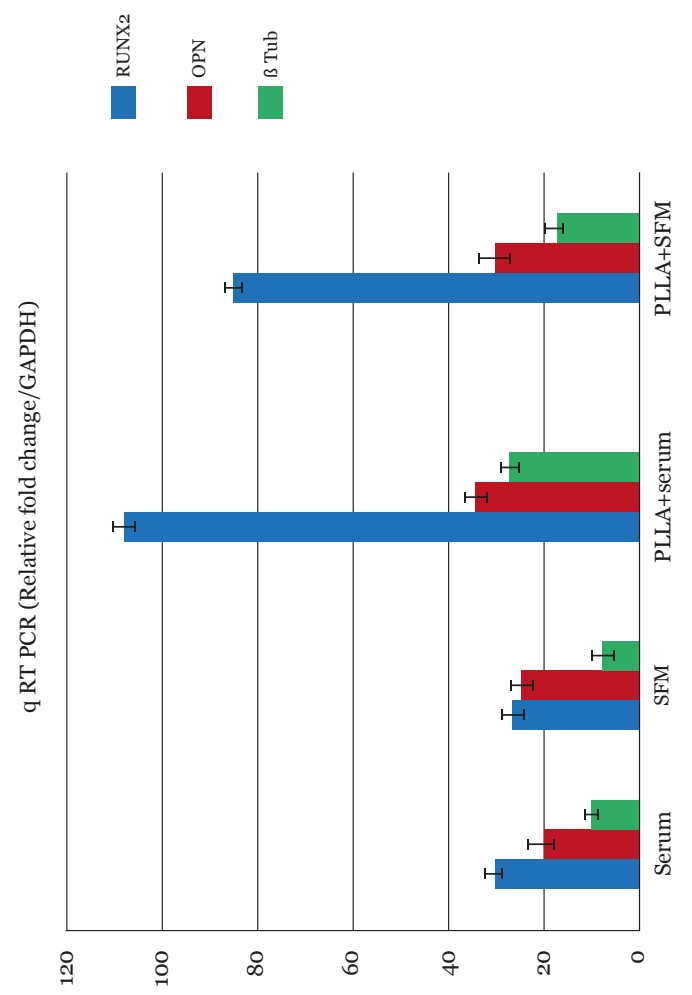

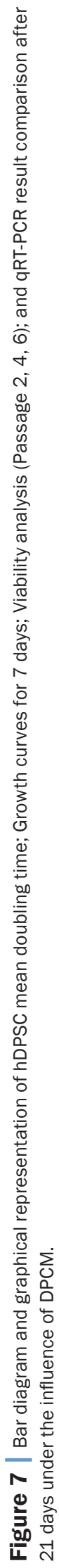




\section{Morphological study of hDPSC}

In the cultures with serum, hDPSC formed tightly packed dense colonies of fibroblast-like spindle shaped cells, which are commonly associated with uncommitted progenitor cells (Figure 4C). The cell passages had similar growth characteristics, and no change in cell shape was found during the culture. These findings indicate that the cells have not undergone spontaneous differentiation during the culture and have maintained their 'stem cell' character. Similarly, on nanofibers, hDPSC attained the typical fibroblast-like morphology attributable to uncommitted stem cells. The cells were found on the surface of the nanofibers as well as entrapped in between the nanofibers, indicating close interaction (Figure 4D). The nanofibers did not favour any other characteristic morphological changes pointing to differentiation during the course of the culture.

Besides the slow proliferation, morphological changes were observed when hDPSC were grown serum-free. hDPSC cultured without nanofibers were short and flattened with short cytoplasmic extensions (Figure 4E). Interestingly, hDPSC grown on nanofibers without serum had extended cytoplasmic processes in contact with the nanofibers and adjacent cells (Figure $4 \mathrm{~F}$ ).

\section{Differentiation analysis after short-term exposure to DPCM}

On short-term exposure to Dental Pulp Conditioned Media (DPCM), the doubling time was significantly lower in the presence of nanofibers, indicating greater proliferation in the presence of nanotopography. hDPSC cultured without nanofibers showed significant changes in morphology after 3 weeks, indicating lineage commitment and differentiation. These cells had a cell body with multiple long interconnecting cytoplasmic processes resembling neurons (Figures 5A-B). After 4 weeks, the cells reached senescence. However, the hDPSC on nanofibers (both in the presence and absence of serum) seemed to retain the spindle shaped fibroblast-like morphology under light microscopy even after 3 weeks (Figures $5 \mathrm{C}$-D).

The scanning electron microscopic results of PLLA nanofibers seeded with hDPSC and grown with serum showed hDPSC entrapment and infiltration into PLLA nanofibers. Predominantly, the cells appeared to be long and spindle shaped retaining their pluripotent "fibroblast"-like morphology. The cellular diameter of these spindle shaped cells was approximately 10 micrometers. SEM images showed close contact and interaction of the hDPSC cytoplasmic processes with the nanofibers. Few short cells with multiple elongated cytoplasmic processes in contact with the nanofibers and the adjacent cells were also present (Figure 6). However, according to our data of gene tracing, expressions of the odontogenic and neurogenic genes (RUNX2, osteopontin, and $\beta$-tubulin III) were higher for the cells cultured in the presence of nanofibers. Also, it was noted that PLLA nanofiber supplemented with serum showed higher levels of the three genes compared to PLLA nanofiber with SFM media (Figure 7D). The results indicate a higher odontogenic and neurogenic differentiation potential of the PLLA nanofiber with serum.

\section{DISCUSSION}

Dental pulp represents a well delimited and separated compartment, which retains its unique histological structure and its stem cell niche. ${ }^{19}$ "Stemness" is not solely an intrinsic property of the stem cell, but a result of the interaction between the stem cell and its niches. ${ }^{14,19}$ Therefore, it becomes necessary to unravel the stem cell niche properties that influence the stem cell fate. This study aimed to study the hDPSC response to two of the niche components - mano-topographical cues and soluble factors. PLLA nanofiber architecture structurally simulates collagen fibers and directly modifies cell behaviours, including adhesion, proliferation, and 
differentiation. The regenerative potential of dental pulp cells/NF-PLLA constructs has been investigated in various studies. ${ }^{21}$ Thus, PLLA nanofibers were used as the in vitro structural biomimetic of the native nanotopography found in the ECM/stem cell niche in vivo. Serum (that contains the nutrients, growth factors, proteins, and hormones) and DPCM were used to assess the stem cell response to soluble factors.

Our study is the first of its kind to assess the combined effect of nanofibers and serum on human dental pulp stem cells. The human dental pulp stem cells cultured with serum had a high proliferation rate and typical stem cell morphology, without any characteristic and morphological changes indicating differentiation. In this study, the cell viability and doubling time were consistent with the results of other studies on human dental stem cells. ${ }^{22}$ Also, cellular viability and proliferation were significantly reduced in serum-free media. Interestingly, in serum-free conditions, hDPSC grown on culture plates acquired morphological features similar to the cell description given by Bonnamain et al. ${ }^{23}$ for the population of hDPSC that had undergone odontoblastic lineage commitment in serum-free supplemented medium.

Comparing the growth characteristics and morphologies of hDPSC in the presence and absence of serum, we conclude that serum (which contains soluble factors, including certain growth factors, proteins, and hormones) plays an important role in stem cell survival, regulation, and proliferation. Cellular morphological changes could be observed with the absence of certain soluble factors found in serum, indicating that these soluble factors regulate the dental stem cell properties. These changes in cell morphology and growth characteristics might indicate difficulty in survival and progressive loss of 'stemness' of the cells in the absence of serum.

Our observation of hDPSC cultures on nanofibers was similar to Deng et al., ${ }^{24}$ who demonstrated that PLLA nanofibers highly supported dental stem cell culture. The nanofibers did not favour any other characteristic morphological changes indicating differentiation during the course of the culture. The 'cellular morphology' is known to influence the organisation of actin cytoskeleton, focal adhesions, cell growth characteristics, cell signalling, and potency. ${ }^{25}$ Thus, by maintaining the typical stem cell morphology, the nanofibers influence the potency and properties of these hDPSC. Previous studies postulate that the nanofiber architecture enhance protein adsorption and therefore contribute to improved cell anchorage, attachment, and growth. ${ }^{26}$ Also, in this study, hDPSC cultured on nanofibers without serum had long cytoplasmic processes, as found in a number of other studies using serum-free media. ${ }^{27}$ Our observations indicate that nanofibers favour greater cell proliferation, even in the absence of the growth factors, proteins, and hormones supplied with the serum. However, the cells that were cultured in the presence of both nanofibers and serum had the highest viability percentage and greater proliferation, proving that both nanofibers and serum together influence the hDPSC fate.

The idea behind short-term induction with DPCM was to study the role of niche nanotopography during exposures to transient biological stimuli in vivo and to assess the effectiveness of the nanofibers to favour pluripotency or differentiation in case of transient changes in the soluble factors. We observed that the transient exposure to DPCM leads to changes indicating differentiation in the hDPSC cultures. This shows that DPCM contains differentiation-inducing soluble factors. The analysis of the available literature illustrates the use of dental pulp stem cell derived conditioned media containing secreted factors in various studies. ${ }^{28}$ However, the use of dental pulp tissue to derive conditioned media has not been described so far. To our knowledge, this is the first study to use dental pulp tissue derived conditioned media. This is also the first time that hDPSC differentiation in the presence of DPCM has been reported in the 
literature. Few studies have used other tissues, such as cardiac tissue, to make conditioned media for inducing differentiation of human mesenchymal stem cells. ${ }^{29}$ Thus, this study is unprecedented because it assesses the influence of short-term induction of differentiation with human dental pulp conditioned media on human dental pulp stem cells.

We observed that on the short-term treatment with DPCM differentiation-inducing factors, the nanofibers maintained the hDPSC high proliferative capacity and prevented terminal differentiation. Absence of nanofibers favoured changes indicating lineage commitment, such as slower proliferation and morphological changes.

SEM images revealed that the cells were in contact with the nanofibers and also with each other, within the porous nanonetwork. Two populations of cells were observed in SEM predominantly long fibroblast-like cells and few short plump cells with short filopodia. These differences in morphologies seen under SEM could point towards changes due to interaction with the nanofibers. They could also suggest a different population subset of hDPSC, showing the heterogeneous nature of hDPSC. ${ }^{30}$ Though the expression of the odontogenic and neurogenic genes (RUNX2, osteopontin, and $\beta$-tubulin III) was higher for the cells cultured in the presence of nanofibers, they did not undergo any characteristic morphological changes. These results suggest that the hDPSC did not undergo terminal differentiation in the presence of nanofibers even after transient exposure to differentiating factors. These findings indicate that DPCM induces molecular changes in hDPSC cultured on nanofibers with neurogenic and odontogenic features, but at a primitive stage. Further investigations, such as proteomics analysis of the conditioned media and protein expression in the hDPSC, are essential to identify the exact molecules influencing the change and to confirm lineage commitment.
Also, the PLLA nanofiber supplemented with serum showed higher levels of the three genes (RUNX2, osteopontin, and $\beta$-tubulin III) compared to PLLA nanofiber with SFM media. The results indicate a higher odontogenic and neurogenic differentiation potential of the PLLA nanofiber with serum. This increased differentiation potential might be attributed to the difference in their chemical composition and surface topography. Wang et al. ${ }^{11}$ confirms that PLLA nanofiber scaffolds enhanced the odontogenic differentiation of hDPSC and mineralization both in vitro and in vivo, and are promising scaffolds for dentin regeneration. Similarly, Soares et al. ${ }^{21}$ showed that poly-L-lactic-acid nanofiber scaffolds promoted the odontogenic potential of dental pulp cells in an inflammatory environment.

hDPSC on nanofibers showed a better proliferation rate compared to the culture without nanofibers. hDPSC had a neuron-like morphology, which is similar to other studies that have demonstrated differentiation of the dental stem cells into neuronal precursors. ${ }^{31}$ The use of nanofibers made of PLLA in our study could also have enhanced the cells to have neuron-like morphologies. ${ }^{32}$ This inclination towards neuron-like morphology supports the hypothesis of the neuroectodermal origin of the human dental pulp stem cells. ${ }^{33}$

Thus, in this study, we observed that nanotopography favours hDPSC proliferation and maintains their pluripotent morphology. Nanotopography and soluble factors (serum and DPCM) together regulate the human dental stem cell properties. The data presented here provides new insights about the nano- and microenvironment of the hDPSC niche, and this will enable us to delineate and understand factors influencing dental pulp stem cell behaviours.

\section{CONCLUSION}

In summary, we showed that nanotopography and soluble factors play a vital role in the human 
dental pulp stem cell regulation. We observed that hDPSC has the ability to sense nanoscale geometric cues from their microenvironment. The final goal of our study is to better understand the complexity that entails the native extracellular matrix (ECM) and stem cell niche in the pulp through the creation of in vitro models. This study thus provides important information and a basis for further investigations prerequisite to using human dental pulp stem cells for clinical therapeutic purposes in dental pathology, pulp regeneration, and new dentin formation.

\section{REFERENCES}

1. Lanza R, Gearhart J, Hogan B, Melton D, Pedersen R, Thomas ED, Thomson J, editors. Essentials of Stem Cell Biology. Cambridge: Academic Press; 2006.

2. Weissman IL, Anderson DJ, Gage F. Stem and progenitor cells: origins, phenotypes, lineage commitments, and transdifferentiations. Annu Rev Cell Dev Biol. 2001;17:387-403. doi: 10.1146/annurev.cellbio.17.1.387.

3. Gronthos S, Brahim J, Li W, Fisher LW, Cherman N, Boyde A, et al. Stem cell properties of human dental pulp stem cells. J Dent Res. 2002;81:531-5. doi: 10.1177/154405910208100806.

4. Gronthos S, Mankani M, Brahim J, Robey PG, Shi S. Postnatal human dental pulp stem cells (DPSCs) in vitro and in vivo. Proc Natl Acad Sci U S A. 2000;97(25):13625-30. doi: 10.1073/pnas.240309797.

5. Maher A, Núñez-Toldrà R, Carrio N, Ferres-Padro E, Ali H, Montori S, Al Madhoun A. The Effect of Commercially Available Endodontic Cements and Biomaterials on Osteogenic Differentiation of Dental Pulp Pluripotent-Like Stem Cells. Dent J (Basel). 2018;6(4). doi: 10.3390/dj6040048.

6. Karaöz E, Doğan BN, Aksoy A, Gacar G, Akyüz S, Ayhan S, et al. Isolation and in vitro characterisation of dental pulp stem cells from natal teeth. Histochem Cell Biol. 2010;133(1):95-112. doi: 10.1007/so0418-009-0646-5.

7. Miura M, Gronthos S, Zhao M, Lu B, Fisher LW, Robey PG, Shi S. SHED: stem cells from human exfoliated deciduous teeth. Proc Natl Acad Sci U S A. 2003;100(10):5807-12. doi: 10.1073/pnas.0937635100.

8. Friedlander LT, Cullinan MP, Love RM. Dental stem cells and their potential role in apexogenesis and apexification. Int Endod J. 2009;42(11):955-62. doi: 10.1111/ j.1365-2591.2009.01622.x.
9. Mitsiadis TA, Woloszyk A, Jimenez-Rojo L. Nanodentistry: combining nanostructured materials and stem cells for dental tissue regeneration. Nanomedicine(Lond). 2012;7(11):1743-53. doi: 10.2217/nnm.12.146.

10. Nishikawa SI, Osawa M. Generating quiescent stem cells. Pigment Cell Res. 2007;20(4):263-70. doi: 10.1111/ j.1600-0749.2007.00388.x.

11. Wang J, Ma H, Jin X, Hu J, Liu X, Li L, Ma PX. The effect of scaffold architecture on odontogenic differentiation of human dental pulp stem cells. Biomaterials. 2011;32(31):7822-30. doi: 10.1016/j.biomaterials.2011.04.034.

12. Brafman DA. Constructing stem cell microenvironments using bioengineering approaches. Physiol Genomics. 2013;45(23):112335. doi: 10.1152/physiolgenomics.00099.2013.

13. Gupte MJ, Ma PX. Nanofibrous Scaffolds for Dental and Craniofacial Applications. J Dent Res. 2012;91(3):227-34. doi: 10.1177/0022034511417441.

14. Khanna-Jain R, Vanhatupa S, Vuorinen A, Sandor GKB, Suuronen R, et al. Growth and Differentiation of Human Dental Pulp Stem Cells Maintained in Fetal Bovine Serum, Human Serum and Serum-free/Xeno-free Culture Media. J Stem Cell Res Ther. 2012; 2(4). doi: 10.4172/2157-7633.1000126.

15. Scadden DT. The stem-cell niche as an entity of action. Nature. 2006;441(7097):1075-9. doi: 10.1038/nature04957.

16. Estrela C, Alencar AH, Kitten GT, Vencio EF, Gava E. Mesenchymal stem cells in the dental tissues: perspectives for tissue regeneration. Braz Dent J. 2011;22(2):91-8.

17. Fitzgerald M, Chiego JD Jr, Heys DR. Autoradiographic analysis of odontoblast replacement following pulp exposure in primate teeth. Arch Oral Biol. 1990;35(9):707-15. doi: 10.1016/ooo3-9969(90)90093-p.

18. Kim DH, Provenzano PP, Smith CL, Levchenko A. Matrix nanotopography as a regulator of cell function. J Cell Biol. 2012;197(3):351-6o. doi: 10.1083/jcb.201108062.

19. Turner LA, Matthew JD. Nanotopography - potential relevance in the stem cell niche. Biomater Sci. 2014;2:1574-94. doi: 10.1039/C4BMoo155A.

20. Sloan AJ, Waddington RJ. Dental pulp stem cells: what, where, how? Int J Paediatr Dent. 2009;19(1):61-70. doi: 10.1111/j.1365-263X.2008.00964.x.

21. Soares DG, Zhang Z, Mohamed F, Eyster TW, Souza Costa CA, Ma PX. Simvastatin and nanofibrous poly (l-lactic acid) scaffolds to promote the odontogenic potential of dental pulp cells in an inflammatory environment. Acta Biomater. 2018;68:190-203. 
22. Alleman M, Low E, Truong K, Huang E, Hill CK, Chen TY, et al. Dental pulp-derived stem cells (DPSC) differentiation in vitro into odontoblast and neuronal progenitors during cell passaging is associated with alterations in cell survival and viability. Int J Med Biomed Res. 2013;2(2):133-41.

23. Bonnamain V, Thinard R, Sergent-Tanguy S, Huet P, Bienvenu G, Naveilhan P, et al. Human dental pulp stem cells cultured in serum-free supplemented medium. Front Physiol. 2013;4:357.

24. Deng XL, Xu MM, Li D, Sui G, Hu XY, Yang XP. Electrospun PLLA/ MWNTs/HA hybrid nanofiber scaffolds and their potential in dental tissue engineering. Key Eng Mater. 2007;330-332:393-6. doi: 10.4028/www.scientific.net/ KEM.330-332.393.

25. Matsuoka F, Takeuchi I, Agata H, Kagami H, Shiono H, Kiyota Y, et al. Morphology-Based Prediction of Osteogenic Differentiation Potential of Human Mesenchymal Stem Cells. PLoS One. 2013;8(2):e55082. doi: 10.1371/journal.pone.0055082.

26. Woo KM, Chen VJ, Ma PX. Nano-fibrous scaffolding architecture selectively enhances protein adsorption contributing to cell attachment. J Biomed Mater Res A. 2003;67(2):531-7.

27. Zainal Ariffin SH, Kermani S, Zainol Abidin IZ, Megat Abdul Wahab RM, Yamamoto Z, Senafi S, et al. Differentiation of Dental Pulp Stem Cells into Neuron-Like Cells in Serum-Free Medium. Stem Cells Int. 2013;2013(250740). doi: 10.1155/2013/250740.
28. Kichenbrand C, Velot E, Menu P, Moby V. Dental pulp stem cell-derived conditioned medium: an attractive alternative for regenerative therapy. Tissue Eng Part B Rev. 2019;25(1):7888. doi: 10.1089/ten.TEB.2018.0168

29. Ramesh B, Bishi DK, Rallapalli S, Arumugam S, Cherian KM, Guhathakurta S. Ischemic cardiac tissue conditioned media induced differentiation of human mesenchymal stem cells into early stage cardiomyocytes. Cytotechnology. 2012;64(5):563-75. doi: 10.1007/s10616-012-9440-7.

30. Shi S, Bartold PM, Miura M, Seo BM, Robey PG, Gronthos S. The efficacy of mesenchymal stem cells to regenerate and repair dental structures. Orthod Craniofac Res. 2005;8(3):191-9. doi: 10.1111/j.1601-6343.2005.00331.x.

31. Aanismaa R, Hautala J, Vuorinen A, Miettinen S, Narkilahti S. Human dental pulp stem cells differentiate into neural precursors but not into mature functional neurons. Stem Cell Discovery. 2012;2(3):85-91. doi: 10.4236/scd.2012.23013.

32. Yang F, Murugan R, Wang S, Ramakrishna S. Electrospinning of nano/micro scale poly(L-lactic acid) aligned fibers and their potential in neural tissue engineering. Biomaterials. 2005;26(15):2603-10. doi: 10.1016/j.biomaterials.2004.06.051.

33. Abe S, Hamada K, Miura M, Yamaguchi S. Neural crest stem cell property of apical pulp cells derived from human developing tooth. Cell Biol Int. 2012;36(10):927-36. 